\title{
Bentuk Lokusi, llokusi, dan Perlokusi Siswa dalam Pembelajaran Tematik
}

\author{
Heny Kusuma Widyaningrum ${ }^{a, 1^{*}}$, Cahyo Hasanudin ${ }^{\text {b, } 2}$ \\ a Prodi Pendidikan Guru Sekolah Dasar, FKIP, Universitas PGRI Madiun \\ ${ }^{\mathrm{b}}$ Program Studi Pendidikan Bahasa dan Sastra Indonesia, FPBS, IKIP PGRI Bojonegoro \\ ${ }^{1}$ heny@unipma.ac.id*; cahyo.hasanudin@,ikippgribojonegoro.ac.id \\ *korespondensi penulis
}

\begin{tabular}{ll}
\hline Informasi artikel & \\
\hline Sejarah artikel: & \\
Diterima & I3 Juni 2019 \\
Revisi & I6 Agustus 2019 \\
Dipublikasikan & 30 Oktober 2019 \\
\hline
\end{tabular}

Kata kunci:

Tuturan, Lokusi, Ilokusi, Perlokusi,

Interaksi Pembelajaran Tematik \begin{abstract}
ABSTRAK
Penelitian ini bertujuan (I) mendeskripsikan tindak tutur lokusi, ilokusi, dan perlokusi siswa terhadap guru dalam pembelajaran tematik di Klegen 02 Madiun. Metode yang digunakan adalah metode deskriptif kualitatif yang mengarah pada pendeskripsian kondisi sesungguhya di lapangan kemudian diuraikan dalam teks. Teknik pengumpulan data menggunakan wawancara, observasi, dan dokumentasi. Teknik analisis data yang digunakan adalah reduksi data, penyajian data, dan penarikan kesimpulan. Hasil penelitian ini adalah I) Tindak tutur lokusi dalam pembelajaran tematik yang dilakukan guru dan siswa maupun siswa ke pada gurunya sudah cukup baik. Intensitasnya tidak sering dengan alasan anak anak sudah terbiasa menyampaikan sesuatu tanpa ada tujuan yang lain, 2) tindak tutur ilokusi siswa terhadap guru terjadi dalam wujud tindak tutur asertif, diretif, dan ekspresif, 3) tindak tutur perlokusi dilakukan untuk mempengaruhi orang lain.

ABSTRACT

This study aims (I) to describe localized, illocutionary, and student-speaking acts of speech acts against teachers in thematic learning at Klegen 02 Madiun. The method used is a qualitative descriptive method that leads to a description of the actual conditions in the field and then described in the text. Data collection techniques using interviews, observation, and documentation. Data analysis techniques used are data reduction, data presentation, and drawing conclusions. The results of this study are I) locus speech acts in thematic learning conducted by teachers and students as well as students to the teacher is good enough. The intensity is not often on the grounds that children are accustomed to convey something without any other purpose, 2) the acts of students' illocutionary acts of speech occur in the form of assertive, directive, and expressive speech acts, 3 ) acts of speech acts are performed to influence others.
\end{abstract}

Key word:

Speech, Locution, Illocution, Perlocution, Thematic Learning Interactions

Copyright (C) 2018 Universitas Ahmad Dahlan. All Right Reserved

\section{Pendahuluan}

Sopan santun dalam berbicara merupakan hal yang wajib diterapkan dalam lingkungan sekolah, khususnya pada jenjang sekolah dasar. Lingkungan sekolah dasar merupakan konteks formal yang menjadi salah satu wujud sopan santun dalam berkomunikasi antara guru dan siswa. Sejak siswa bersekolah di bangku kelas satu, guru wajib memberikan panutan yang baik bagi anak didiknya. Oleh karena itu, sopan santun dalam lingkungan sekolah dasar merupakan salah satu wujud penerapan dan objek dalam tindak tutur.

Misalnya mata pelajaran bahasa Indonesia yang menurut Hasanudin (2016) sudah diajarkan sedini mungkin dengan berbagai standar kompetensi dan kompetensi dasar yang berbeda.
Berkaitan dengan lingkungan sekolah dasar, berarti berkaitan erat dengan pembelajaran tematik. Pembelajaran tematik merupakan pembelajaran yang mengaitkan tema dengan beberapa mata pelajaran yang dapat memberikan pengalaman bermakna dan berpusat pada siswa (Widyaningrum, 2012). Apabila dibandingkan dengan pembelajaran yang tidak tematik atau hanya diajarkan per mata pelajaran saja (seperti muatan lokal, agama), pembelajaran tematik lebih dominan diajarkan karena hampir semua mata pelajaran terintegrasi melalui tema yang sudah ditentukan.

Pada pembelajaran tematik SK dan KD diseragamkan dengan berbagai matapelajaran untuk menumbuhkan kemampuan berbahasa, berbicara, menalar, dan kesantunan. Kesantunan berbahasa 
merupakan sebuah hukum yang dibuat manusia untuk berkomunikasi. Kesantunan merupakan perilaku sosial yang telah menjadi kesepakatan bersama dalam masyarakat (Niyasari, 2015). Bentuk kesantunan terlihat salah satunya melalui tindak tutur antar komunikan. Tindak tutur tersebut bersifat psikologis dan terjadi sesuai kemampuan bahasa penutur (Apriastuti, 2017). Dengan manusia melakukan tindak tutur berarti berupaya menjadi manusia yang berbahasa dengan baik, salah satunya melalui pembelajaran dan setiap tuturan yang diucapkan harus dipertanggungjawabkan (Rohmadi, 2010).

Kesantunan bertutur kata sangat penting dalam kehidupan sehari-hari. salah satunya pada pembelajaran tematik. Hal tersebut dikarenakan agar siswa sekolah dasar mampu berkomunikasi secara efektif dengan guru atau sesama teman. Markhamah dan Sabardila (2009) menjelaskan bahwa tujuan kesantunan berbahasa supaya mitra tutur memahami dan tidak tersinggung tuturan yang diucapkan oleh penutur. Pada interaksi di kelas, norma kesantunan yang berupa tindak tutur terlihat pada perilaku verbal, baik terjadi pada guru maupun siswa (Kurniadi, dkk, 2017).

Kesantunan berbahasa jarang digunakan pada peristiwa tutur dalam obrolan, dari segi obrolan siswa dengan guru, kepala sekolah, siswa dengan siswa, dan siswa dengan masyarakat. Sering dijumpai hal itu suatu pola tindakan tuturan yang salah dalam menempatkannya. Seorang siswa menggunakan tuturan yang seadanya terhadap seorang guru. Interaksi yang kurang sopan terkadang membuat efek kurang baik seperti percakapan siswa dengan guru, sebaiknya menggunakan bahasa yang formal dengan istilah memberi rasa hormat kepada orang yang lebih tua darinya.

Tinggi rendahnya kesantunan berbahasa siswa di dalam kelas dipengaruhi oleh beberapa hal, antara lain tayangan yang dilihat di televisi maupun handphone, ketidaksadaran orang tua dalam berkata yang biasa ditiru oleh anaknya (Wahyuni, 20I6). Untuk mengatasi kurang santunnya berbahasa siswa, berbagai pihak perlu menanamkan cara bertutur kata yang santun sejak dini, mulai dari orang tua, guru, dan masyarakat sekitar. Salah satu caranya yaitu siswa dilatih berbicara santun saat berinteraksi dengan guru dan antarsiswa (Leech, 20II).

Berbicara merupakan kemampuan berkomunikasi kepada orang lain dalam bahasa lisan. Kegiatan berbicara yang berhubungan penutur, petutur, dan pesan disebut intekasi atau peristiwa tutur. Chaer (2010) menegaskan bahwa peristiwa tutur merupakan bentuk ujaran yang melibatkan dua orang (penutur dan petutur) pada tempat dan situasi tertentu. Selanjutnya, tindak tutur dilihat pada makna dari tindakan dalam tuturannya.

Tindak tutur dalam peristiwa tutur merupakan proses komunikasi. Dalam kehidupan sehari-hari, manusia pasti melakukan peristiwa tutur dengan tujuan antara penutur dan petutur samasama mendapat informasi. Tindak tutur memiliki beragam jenis, salah satunya penggolongan berdasarkan sifat hubungannya yang mencakup tindak tutur lokusi, ilokusi, dan perlokusi. Lokusi adalah tindak tutur dalam bentuk kalimat yang bermakna dan dapat dipahami (Austin \& Searle, dalam Rahardi, 2009). Ilokusi adalah tindak tutur yang biasanya diidentifikasikan dengan kalimat performatif yang eksplisit. Perlokusi adalah tindak tutur yang dapat mempengaruhi mitra tutur (Pamungkas, 2012).

Tindak tutur yang dilakukan siswa pada pembelajaran tematik memiliki maksud dan tujuan tertentu. Tujuan dan maksud tersebut diungkapkan tidak secara langsung dikomunikasikan dengan saat pembelajaran tematik dengan guru melalui implikasiimplikasi yang mewajibkan siswa untuk memahaminya. Berdasarkan hal tersebut, peneliti ingin mengetahui secara langsung tindak tutur lokusi, ilokusi, dan perlokusi dalam interaksi pembelajaran tematik siswa kelas V di SDN Klegen 02 Madiun.

\section{Metode penelitian}

Jenis penelitian yang digunakan dalam penelitian ini yaitu penelitian kualitatif karena penelitian mengarah pada pendeskripsian kondisi sesungguhnya di lapangan yang kemudian diuraikan dalam teks. Penelitian ini bersifat deskriptif kualitatif yang mendeskripsikan tindak tutur siswa kelas V terhadap guru kelasnya pada pembelajaran tematik tema 4 subtema I "Peredaran Darahku Sehat" di SDN Klegen 02 Madiun.

Sumber data dalam penelitian ini adalah informasi yang ditemukan penelitian di lapangan. Dalam penelitian kualitatif, data dapat berupa dokumen, transkip peristiwa atau objek-objek lainnya. Teknik pengumpulan data yang digunakan dalam penelitian ini adalah wawancara, observasi, dan dokumentasi. Instrumen penelitian dalam penelitian ini adalah pedoman wawancara dan observasi.

Teknik analisis data yang digunakan adalah analisis data kualitatif dengan menggunakan metode analisis data deskripsi kualitatif. Prosedur penelitian yang pertama adalah tahap pra-lapangan yaitu menyusun rancangan penelitian, memlilih lokasi penelitian, mengurus surat perizinan, memilih informan, dll. Prosedur penelitian yang kedua adalah tahap pekerjaan lapangan yaitu melaksanakan 
penelitian untuk mengumpulkan data, menganalisis data-data yang terkumpul.

\section{Hasil dan Pembahasan}

I. Tindak Tutur Lokusi Siswa terhadap Guru dalam Pembelajaran Tematik

Tindak tutur yang dilakukan siswa Kelas IV SDN Tinap 3, Kecamatan Sukomoro, Kabupaten Magetan kepada guru dapat dilihat pada data berikut.

"saya sakit pak"

Gambar I. Data lokusi I

Wujud tuturan pada data I merupakan bentuk tindak tutur lokusi karena tuturan tersebut hanya sebuah tuturan yang menyatakan suatu hal tidak untuk melakukan ataupun mempengaruhi lawan tuturnya. Tuturan tersebut dituturkan oleh siswa saat ditanya guru kenapa tidak masuk kemarin.

Tindak tutur lain diucapkan siswa saat ditanya guru terkait aktivitas di rumah. Hal ini dapat dilihat pada data berikut.

"Membantu ibu
menyapu, memasak dan
mencuci"

Gambar 2. Data lokusi 2

Wujud tuturan pada data 2 merupakan tindak tutur lokusi karena tuturan tersebut hanya sebuah tuturan yang menyatakan suatu hal tidak untuk melakukan ataupun mempengaruhi lawan tuturnya. Tuturan tersebut dituturkan oleh siswa saat ditanya guru aktivitas apa saja yang kalian lakukan di rumah.

Tindak tutur lain diucapkan siswa saat ditanya guru terkait tugas melompoj yang akan dikerjakan besama-sama. Hal ini dapat dilihat pada data berikut.

$$
\begin{array}{|c|}
\hline \begin{array}{c}
\text { "Hujan badai sama } \\
\text { pohon tumbang" }
\end{array} \\
\hline \text { Gambar 3. Data lokusi } 3
\end{array}
$$

Wujud tuturan pada data 3 merupakan tindak tutur lokusi karena tuturan tersebut hanya sebuah tuturan yang menyatakan suatu hal tidak untuk melakukan ataupun mempengaruhi lawan tuturnya. Tuturan tersebut dituturkan oleh siswa saat ditanya guru bencana alam apa yang akan kalian deskripsikan bersama teman satu kelompok.

Tindak tutur lokusi dalam pembelajaran tematik yang dilakukan guru dan siswa maupun siswa ke pada gurunya sudah cukup baik. Intensitas dalam tindak tutur lokusi dalam pembelajaran di dalam kelas tidak sering dengan alasan anak anak sudah terbiasa menyampaikan perihal tanpa adanya tujuan atau maksud lain. Sehingga tuturan anak juga dapat dengan mudah di pahami oleh lawan bicaranya.
Hasil tersebut sesuai dengan pendapat Pamungkas, (2012) bahwa tindak lokusi merupakan tuturan tanpa adanya tendensi atau mempengaruhi mitra tutur. Tindak lokusi mudah diidentifikasi karena cendurung bisa dilakukan tanpa melibatkan konteks. Penelitian Rahadani \& Suwarna (20I4) menunjukkan penggunaan ilokusi bermodus deklaratif atau kalimat berita (perintah) yang berfungsi untuk memberi tahu pihak lain. Penelitian Susmita (2019) menunjukkan bahwa tindak tutur lokusi kelas X SMA Negeri 8 Kerinci dalam pembelajaran bahasa Indonesia berbentuk berita, tanya, dan perintah. Kedua hasil penelitian tersebut sejalan dengan penelitian Sari (20I5) bahwa bentuk lokusi yang digunakan oleh guru dan murid dalam membuka, menerangkan, dan menutup pelajaran berupa tuturan bertanya, menginformasikan, menyatakan.

Berdasarkan temuan di atas dan berdasarkan teori yang telah disampaikan bahwa penggunaan tindak tutur lokusi sering di gunakan oleh guru dan siswa dalam kegiatan pembelajaran. Seringnnya penggunaan lokusi dikarenakan dalam lingkungan pendidikan dan ditambah dengan lingkungan masyarakat Jawa sangat erat kaitannya dengan penerapan tindak tutur kata yang baik. Siswa kepada orang yang lebih tua hendaknya sangat disarankan untuk memakai tindak tutur kata yang baik. Oleh karena itu sangat sering kita jumpai seseorang yang lebih muda atau kepada teman yang baru kenal dalam lingkungan masyarakat jawa menggunakan tindak tutur kata lokusi yang baik sesuai dengan tata krama yang berlaku di dalam masyarakat Jawa.

\section{Tindak Tutur Ilokusi Siswa terhadap Guru dalam Pembelajaran Tematik}

Bentuk tuturan ilokusi yang dilakukan siswa Kelas IV SDN Tinap 3, Kecamatan Sukomoro, Kabupaten Magetan kepada guru berbentuk tuturan asertif, direktif, dan ekspresif.

Bentuk tuturan asertif dapat dilihat pada gambar berikut.

$$
\begin{array}{|c|}
\hline \begin{array}{c}
\text { "Belum, masih kurang } \\
\text { pak" }
\end{array} \\
\text { Gambar 4. Data ilokusi I }
\end{array}
$$

Wujud tuturan pada gambar 4 merupakan tindak tutur asertif karena tuturannya termasuk ke dalam bentuk tuturan menyatakan. Tuturan tersebut dituturkan oleh siswa saat guru bertanya apakah sudah selesai dalam mengerjakan tugas.

Bentuk tuturan direktif yang dilakukan siswa dapat dilihat pada gambar berikut.

$$
\begin{gathered}
\begin{array}{c}
\text { "Diletakkan saja ya, } \\
\text { Pak" }
\end{array} \\
\text { Gambar 5. Data ilokusi } 2
\end{gathered}
$$


Wujud tuturan pada gambar 5 termasuk tindak tutur direktif. Dikatakan tindak tutur direktif karena tuturannya termasuk dalam tuturan memohon. Tuturan tersebut dituturkan oleh siswa kepada guru saat guru menjelaskan.

Bentuk tuturan yang dilakukan siswa pada tindak tutur ilokusi yang terakhir adalah tuturan ekspresif. Tuturan ini dapat dilihat pada gambar berikut.

$$
\begin{gathered}
\text { "La kok iso tidak } \\
\text { menghemat, menghemat } \\
\text { yo" } \\
\text { Gambar 6. Data ilokusi } 3
\end{gathered}
$$

Wujud tuturan pada gambar 6 jika diterjemahkan ke dalam bahasa Indonesia adalah "Mengapa bisa tidak menghemat. Menghemat ya.". Wujud tuturan pada gambar 6 merupakan bentuk tindak tutur ekspresif karena tuturannya termasuk dalam tuturan menyalahkan. Tuturan tersebut dituturkan siswa kepada temannya ketika guru menanyakan pendapat.

Tindak tutur ilokusi menurut Austin \& Searle dalam Rahardi (2009) merupakan sesuatu hal yang memiliki maksud dan fungsi dalam aktivitas bertutur. Chaer (2010) memberikan contoh tindak tutur ilokusi "Sudah hampur pukul tujuh" dan "Ujian nasional sudah dekat". Kedua tuturan ini diucapkan guru kepada siswa dengan tujuan memberikan informasi yang mengandung tujuan atau maksud.

Bentuk tindak tutur asertif. Bentuk asertif ini sering dilakukan siswa ketika siswa merasa sudah jenuh dengan pembelajaran, ketika siswa mengeluh tentang tugas-tugas yang diberikan. Baik itu di ucapkan secara tidak sengaja maupun sengaja tentu siswa sering mengucapkan tindak tutur asertif ini. Fungsi tindak tutur Apriastuti (2017) asertif menurut adalah menyampaikan kebenaran proposisi dalam bentuk berspekulasi, menyatakan, menyebutkan, menuntut, memberikan kesaksikan, mengakui, melaporkan, dan menunjukkan. Tindak tutur asertif menurut Nirmala (20I5) pernyataan yang bersifat netral.

Bentuk tindak tutur direktif. Bentuk direktif ini berwujud komunikasi guru dengan murid yang terjalin baik sehingga guru dengan murid atau pun murid dengan murid akan sering menggunakan tindak tutur ini ketika siswa merasa dirinya benar atau siswa itu ingin melakukan sesuatu. Bentuk tutur direktif seperti yang telah dipaparkan dalam hasil penelitian memang merupakan bentuk tutur yang dilakukan oleh siswa kelas IV SDN Tinap 3, Kecamatan Sukomoro, Kabupaten Magetan. Koizumi (I995:I49) dalam Tanjung menjelaskan bahwa ilokusi direktif merupakan ujaran yang ditampilkan dalam konteks wacana yang mengarah pada pemberi dan penerima keuntungan antara penutur dan petutur.

Bentuk tindak tutur ekspresif. Bentuk ekspresif ini diujarkan guru kepada murid, murid kepada murid. Seperti halnya antar murid saling mengucapkan ungkapan berterimakasih, ungkapan permintaan maaf dan ungkapan pujian. Tentunya guru juga sering menyampaikan tuturan ekspresif ini kepada anak didiknya. Tindak tutur ekspresif menurut Ariyanti dan Zulaeha (2017) sebagai pujian, umpatan, keluhan, ucapan terima kasih, salam, ucapan belasungkawa, dan meminta maaf.

Penelitian Kentary, Ngalim, \& Prayitno (20I5) menunjukkan bahwa dalam kegiatan nonformal ditemukan bentuk tindak tutur asertif, direktif, dan ekspresif. Setiap peristiwa tutur selalu terdapat tindak tutur ilokusi.

\section{Tindak Tutur Perlokusi Siswa terhadap Guru dalam Pembelajaran Tematik}

Bentuk tuturan perlokusi yang dilakukan siswa Kelas IV SDN Tinap 3, Kecamatan Sukomoro, Kabupaten Magetan kepada guru dapat dilihat pada gambar berikut.

"Kita harus menghemat
penggunaannya!"
Gambar 7. Data perlokusi I

Wujud tuturan pada gambar 7 merupakan bentuk tindak tutur perlokusi karena tuturan bisa mempengaruhi atau memberikan efek pada lawan tuturnya. Tuturan tersebut dituturkan oleh siswa saat ditanya guru tindakan apa yang harus dilakukan untuk melestarikan lingkungan.

Tindak tutur lain dapat dilihat pada gambar berikut.

$$
\begin{gathered}
\hline \text { "Dengan tidak } \\
\text { digunakan secara terus } \\
\text { menerus!" } \\
\text { Gambar 8. Data perlokusi } 2
\end{gathered}
$$

Wujud tuturan pada gambar 8 termasuk tindak tutur perlokusi. Dikatakan tindak tutur perlokusi karena tuturan tersebut tuturan yang dapat mempengaruhi/ efek pada lawan tuturnya. Tuturan tersebut dituturkan oleh siswa saat ditanya guru tindakan apa yang harus dilakukan untuk melestarikan lingkungan.

Tindak turu perlokusi terakhir yang dilakukan siswa kepada guru dapat dilihat pada gambar berikut.

$$
\begin{gathered}
\text { "Dengan } \\
\text { menggunakannya secara } \\
\text { bijaksana!" } \\
\text { Gambar 9. Data perlokusi } 3
\end{gathered}
$$

Wujud tuturan pada gambar 9 termasuk tindak tutur perlokusi. Dikatakan tindak tutur 
perlokusi karena tuturan tersebut tuturan yang dapat mempengaruhi/ efek pada lawan tuturnya. Tuturan tersebut dituturkan oleh siswa saat ditanya guru tindakan apa yang harus dilakukan untuk melestarikan lingkungan.

Tindak tutur perlokusi menurut Susmiati, Andianto, \& Husniah (2013) timbul karena tuturan yang diucapkan penutur mengandung bujukan, tipuan, rayuan dan sebagainya. Seperti halnya tuturan guru mampu memberikan motivasi murid lebih baik atau malah memberikan efek ketakutan. Perlokusi menurut Eriyanti (20017) adalah efek tuturan terhadap pendengarnya.

Penelitian Insani \& Sabardila (2016) menunjukkan bahwa fungsi perlokusi yang terkandung dalan tindak tutur guru bahasa Indonesia sejalan dengan tujuan sosial bersifat santun dan menyenangkan.

\section{Persantunan}

Terima kasih kepada semua pihak yang telah membantu hingga dapat terbitnya artikel ini. Terima kasih pula kepada tim redaksi dan tim reviewer Bahastra yang telah membantu penerbitan naskah ini.

\section{Daftar pustaka}

Apriastuti, N. N. A. A. (2017). Bentuk, fungsi dan jenis tindak tutur dalam komunikasi siswa di kelas IX Unggulan SMP PGRI 3 Denpasar. Jurnal Imiah Pendidikan dan Pembelajaran. I(I). 38-47. Https://ejournal.undiksha.ac.id/index.php/ IIPP/article/view/I I960/763I

Ariyanti, L. D. dan Zulaeha, I. (2017). Tindak tutur ekspresif humanis dalam interaksi pembelajaran di SMA Negeri I Batang: Analisis wacana kelas. Seloka: Jurnal Pendidikan Bahasa dan Sastra Indonesia, 6(2),

I I I-I 22 .

Https://journal.unnes.ac.id/sju/index.php/ seloka/article/view/I7272/8724.

Chaer, A. (2010). Kesantunan Berbahasa. Jakarta, Indonesia: PT Rineka Cipta

Eriyanti, R. W. (2017). Penalaran dalam tuturan lisan guru pada pembelajaran di SMP Kota Malang. Litera, I6(I), 78-95. Https://journal.uny.ac.id/index.php/litera/ article/view/I4252/9439.

Hasanudin, Cahyo. 2016. Pembelajaran membaca permulaan dengan menggunakan media aplikasi bamboomedia bmgames apps pintar membaca sebagai upaya pembentukan karakter siswa SD menghadapi MEA. Jurnal Pedagogia, 5 (I), $\mathrm{I}-\mathrm{I} 2$.

Http://ojs.umsida.ac.id/index.php/peda gogia/issue/view/I4.

Insani, E. N. \& Sabardila, A. (2016). Tindak tutur perlokusi guru dalam pembelajaran bahasa Indonesia kelas XI SMK Negeri I Sawit Boyolali. Jurnal Penelitian Humaniora, I7(2), I76-I84.

Http://journals.ums.ac.id/index.php/huma niora/article/view/2509/I686.

Kentary, A., Ngalim, A., \& Prayitno, H. J. (2015). Tindak tutur ilokusi guru berlatar belakang budaya Jawa: Perspektif gender. Jurnal Penelitian Humaniora, I6(I), 6I-7I. Http://journals.ums.ac.id/index.php/huma niora/article/view/I522/I055.

Kurniadi, F., Hilaliyah, H., \& Hapsari, S. N. (2017). Membangun karakter peserta didik melalui kesantunan berbahasa. aksiologiya: Jurnal Pengabdian Kepada Masyarakat, 2(I), I-7.

Leech, G. (20I I). Prinsip-prinsip pragmatik (terj. Oka). Jakarta, Indonesia: UI Press.

Markhamah dan Sabardila, A. (2009). Analisis kesalahan dan kesantunan berbahasa. Surakarta, Indonesia: UMS Press.

Nirmala, V. (20I5). Tindak tutur ilokusi pada iklan komersial Sumatera Ekspres. Kandai, II(2), I39-I50.

Https://ojs.badanbahasa.kemdikbud.go.id/j urnal/index.php/kandai/article/view/222/ 7I.

Niyasari, D. A. (2015). Kesantunan Berbahasa dalam interaksi jual beli di Pasar Babebo Kabupaten Jember. Skripsi. Universitas Jember.

Pamungkas, S. (20I2). Bahasa Indonesia dalam berbagai perspektif. Yogyakarta, Indonesia: CV Andi Offset.

Rahadini, A. A. \& Suwarna. (20I4). Kesantunan berbahasa dalam interaksi pembelajaran bahasa Jawa di SMP N I Banyumas. Lingtera, (I) 2 , I36-I 44. Https://journal.uny.ac.id/index.php/litp/a rticle/view/259I/2I4I.

Rahardi, K. (2009). Sosiopragmatik. Jakarta, Indonesia: PT Gelora Aksara Pratama. 
Rohmadi, M. (2010). Pragmatik: Teori dan analisis. Surakarta, Indonesia: Yuma Pustaka.

Sari, N. (2015). Kajian lokusi, ilokusi, dan perlokusi dalam wacana kelas akselerasi SMPN I Kota Bengkulu. Diksa,I(I), I8-25. Https://ejournal.unib.ac.id/index.php/jurn aldiksa/article/view/3I38/I587.

Susmiati, S., Andianto, M. R., \& Husniah, F. (2013). Tindak tutur ekspresif guru terhadap siswa dalam pembelajaran bahasa Indonesia kelas VIII SMP Negeri 7 Jember. Pancaran, 2(2), I49-I60,

Https://jurnal.unej.ac.id/index.php/pancar an/article/view/691/509.

Susmita, N. (2019). Tindak tutur guru dan siswa dalam pembelajaran bahasa Indonesia. $\ddot{1 i} C E T$,
$4(\mathrm{I})$

Https://jurnal.iicet.org/index.php/jpgi/arti cle/view/353/355.

Tanjung, A. (2014). Tindak lokusi, ilokusi, dan perlokusi tuturan direktif yang ditandai oleh verba yarimorai dalam wacana dialog bahasa Jepang. Metalingual, I2(I), I-I4. Http://metalingua.kemdikbud.go.id Ljurnal/index.php/metalingua/article/view 36/30.

Wahyuni, S. (2016). Kesantunan berbahasa siswa dalam wacana diskusi kelas. DISER TASI dan TESIS Program Pascasarjana UM.

Widyaningrum, Retno. (2012). Model Pembelajaran Tematik Di SD Mi/SD. Jurnal Cendekia. IO(I). 